\title{
Kredibilitas Portal Berita Online Dalam Pemberitaan Peristiwa Bom Sarinah Tahun 2016 (Analisis Isi Portal Berita Detik.com dan Kompas.com Periode 14 Januari- 14 Februari 2016)
}

\author{
Praptika Handiyani \\ Program Studi Ilmu Komunikasi FPSB UII, \\ Anang Hermawan \\ Program Studi Ilmu Komunikasi FPSB UII
}

\begin{abstract}
Abstrak
Tujuan penelitian ini adalah untuk memberikan gambaran awal bagi masyarakat terkait kredibilitas berita yang disiarkan portal berita daring Detik.com dan Kompas.com dalam insiden bom Sarinah periode 14 Januari sampai 14 Februari 2016. Penelitian dilakukan di portal berita daring media Detik .com dan Kompas.com dengan menggunakan analisis isi kuantitatif. Analisis kuantitatif digunakan untuk mengukur kredibilitas portal berita daring dengan teori objektivitas pemberitaan media massa yang diajukan oleh Denis McQuail. Dengan melihat dimensi faktualitas dan ketidakberpihakan melalui enam aspek di dalamnya seperti factualness, accuracy, kelengkapan, news value, balance dan neutrality. Berdasarkan hasil total skor enam aspek penelitian tersebut, penelitian ini menemukan bahwa nilai kredibilitas portal berita daring Kompas.com lebih tinggi daripada nilai kredibilitas Detik.com di berita Bom Sarinah periode 14 Januari sampai 14 Februari 2016.
\end{abstract}

Kata Kunci: bom sarinah, kredibilitas berita, media daring, analisis isi

\begin{abstract}
Te purpose of research is to provide an initial picture for the community related to the credibility of news presented daring news portal Detik.com and Kompas.com in the news of Bomb incidents Sarinah period January 14 to February 14, 2016. Research conducted in the news daring media Detik .com and Kompas.com by using quantitative content analysis that is measuring the credibility of daring news portal with objectivity theory of mass media reporting proposed by Denis McQuail. By looking at the dimensions of factuality and dimensional impartiality with six aspects in it such as factualness, accuracy, completeness, news value, balance and neutrality. Based on the results of the total score of the six aspects of research that Factualness, accuracy, completeness, relevance, balance and neutrality and indicators in it, can be drawn conclusion that the credibility value of daring news portal Kompas.com higher than the value of credibility Detik.com in the news Bom Sarinah the period January 14 to February 14, 2016.
\end{abstract}

Keywords: Sarinah bomb, news credibility, daring media, content analysis. 


\section{Pendahuluan}

Peristiwa pengeboman yang terjadi di Jakarta pada 14 Januari 2016 silam, cukup mengusik kedamaian masyarakat Indonesia sehingga menjadi satu peristiwa besar yang menarik perhatian masyarakat. Alasannya karena peristiwa itu terjadi di Jakarta yang merupakan Ibu Kota Negara Indonesia, dan peristiwa pengeboman terbesar yang terjadi kembali setelah Bom Bali pada tahun 2005. Berita mengenai peristiwa pengeboman ini begitu cepat menyebar ke telinga masyarakat, baik masyarakat Jakarta maupun masyarakat Indonesia secara luas. Kekuatan media massa berperan penting dalam penyebaran informasi peristiwa pengeboman ini kepada masyarakat. Bagi media massa sendiri, dengan adanya peristiwa ini, menjadi lahan berita yang bernilai tinggi. Media massa menganggap bahwa setiap perkembangan peristiwa pengeboman di Jakarta merupakan informasi yang menarik dan harus segera diberitakan kepada masyarakat.

Peristiwa pengeboman ini terjadi pada pukul 10.39 ketika dua buah ledakan yang hampir secara bersamaan terjadi di Gerai Starbucks dan Pos Polisi yang terletak di Jalan MH Thamrin, Jakarta Pusat tepatnya di depan Gedung Sarinah. Akibat ledakan tersebut, orang-orang berhamburan keluar gedung dan polisi lalu lintas berdatangan ke lokasi kejadian.Akibat dari peristiwa pengeboman ini, tiga puluh empat orang menjadi korban. Dikabarkan delapan orang tewas, satu orang tewas merupakan warga negara Kanada, tiga orang warga sipil, empat diantaranya adalah pelaku teror. Sementara korban luka sebanyak dua puluh enam orang, lima diantaranya adalah anggota kepolisian. Karena keseluruhan pelaku tewas di lokasi kejadian, polisi tidak dapat meringkuk tersangka dalam peristiwa ini. Polisi menduga peristiwa pengeboman yang terjadi di Jalan MH Thamrin tersebut merupakan aksi terorisme yang didalangi oleh Bahrudin Naim yang merupakan kelompok Islamic State in Iraq and Syria (ISIS) Asia Tenggara yang saat ini tengah berada di Suriah. Hingga saat ini, Bahrun Naim masih menjadi buronan polisi.

Aksi pengeboman di Indonesia kerap kali dikaitkan dengan aksi terorisme. Terorisme adalah serangan terencana dan terkoordinasi yang dilakukan oleh individu atau kelompok yang memiliki tujuan untuk membangkitkan perasaan tidak aman pada sekelompok masyarakat. Aksi terorisme biasanya terjadi secara tiba-tiba dengan target korban jiwa yang acak dan merupakan warga sipil. Aksi terorisme dapat dilakukan dengan dua cara yakni secara fisik (tubuh) dan/atau non fisik (psikis). Aksi teror secara fisik adalah aksi teror yang melibatkan fisik (tubuh) manusia yang dimana dapat mengakibatkan kematian seperti halnya pemukulan dan peledakan bom, 
sedangkan non fisik (psikis) adalah tindakan yang dilakukan dengan cara penyebaran isu yang menakut-nakuti, ancaman, penyanderaan dan lain sebagainya. Terorisme dapat dilakukan oleh individu atau kelompok. Di Indonesia sendiri, aksi teror seringkali dilakukan secara fisik yakni peledakan bom bunuh diri atau peledakan bom di pusat keramaian yang dilakukan oleh individu atau kelompok dengan alasan tertentu. Alasan yang kerap kali muncul sebagai dasar individu atau kelompok rela melakukan aksi pengeboman adalah rasa nasionalisme, kefanatikan terhadap suatu agama, dan balas dendam.

Melalui peristiwa ini, kita dapat melihat bagaimana media massa menjalankan tanggung jawabnya dalam menyebar luaskan informasi kepada audiens pembacanya. Idealnya, media massa berfungsi sebagai media Informasi yang mana harus memenuhi kebutuhan informasi masyarakat. Pemberitaan peristiwa bom Sarinah menjadi contoh untuk membuktikan sejauh mana objektivitas media massa dapat dipertahankan di era moderen yang segala sesuatunya harus tersaji dengan cepat. Kualitas informasi yang didapat oleh masyarakat terkait dengan peristiwa Bom Sarinah bergantung pada kredibilitas berita yang disajikan oleh media massa.

Diantara beragam media massa, portal berita daring menjadi salah satu media massa yang memiliki kekuatan penting dalam menyebarkan informasi peristiwa Bom Sarinah kepada masyarakat. Portal berita daring seringkali dijadikan sebagai sumber referensi terdepan bagi masyarakat karena portal berita daring selalu up to date dalam memberitakan setiap peristiwa yang terjadi di masyarakat. Namun, di balik keunggulannya tersebut, muncul isu terkait kurangnya kredibilitas berita pada portal berita daring. Hal ini dikarenakan berita-berita yang disajikan portal berita daring cenderung ringkas, dan kurang memberikan perspektif bagi pembacanya.

Dari sisi eksistensi portal berita daring, peneliti mengambil dua portal berita daring yang paling diperhitungkan oleh masyarakat Indonesia, yakni Detik.com dan Kompas.com. Dua portal ini merupakan dua diantara sekian banyaknya portal berita daring yang memiliki popularitas cukup tinggi di Indonesia berdasarkan banyaknya pengunjung kedua situs tersebut versi Alexa.com per 12 April 2016. Sementara dari sisi gaya pemberitaan, portal berita Detik.com sangat luas dalam menyajikan pemberitaan mulai dari pemberitaan hard news yang mana harus segera diberitakan ke masyarakat hingga pemberitaan yang remeh temeh. Sementara Kompas.com dikenal sebagai portal berita daring yang selktif dalam menyajikan suatu pemberitaan kepada masyarakat. Peneliti memfokuskan pada kategori hard news pada masing-masing portal berita daring 
dengan periode pemberitaan peristiwa Bom Sarinah dari 14 Januari 2016 hingga 14 Februari 2016.

Berdasarkan uraian di atas, peneliti akan berupaya mengeksplorasi presentasi kredibilitas pemberitaan Bom Sarinah pada portal berita daring Detik.com dan Kompas.com periode 14 Januari- 14 Februari 2016 berdasarkan dimensi factuality dan dimensi impartiality. Oleh karenanya, dapat dirumuskan pertanyaan penelitian utama: "Sejauh mana Kredibilitas pemberitaan bom Sarinah pada portal berita daring Detik.com dan Kompas.com periode 14 Januari- 14 Februari 2016?”. Sebagai pengerucutan dari kebutuhan menganalisis kredibilitas pemberitaan dengan dimensi factuality dan dimensi impartiality, pertanyaan utama di atas dapat dilengkapi dengan enam pertanyaan pendamping, dengan sub dimensi faktualitas, akurasi, kelengkapan informasi, relevansi (nilai berita), balance, dan netralitas.

Tujuan peneniltian ini adalah untuk memberikan gambaran awal bagi masyarakat terkait dengan kualitas berita yang disajikan portal berita daring Detik.com dan Kompas.com dalam pemberitaan peristiwa Bom Sarinah periode 14 Januari-14 Februari 2016. Apabila memang terbukti bahwa kedua portal berita daring tersebut memang telah mampu menjaga kredibilats pemberitaannya, maka hal tersebut dapat memberikan gambaran awal bagi masyarakat terkait dengan kualitas portal berita daring yang selama ini mereka gunakan sebagai referensi informasi. Sebaliknya, apabila nantinya kedua portal berita daring tersebut terbukti tidak mampu menjaga kredibilitas pemberitaannya. Hasil dari penelitian ini dapat digunakan sebagai bahan pembelajaran bagi kedua portal berita daring yang diteliti maupun portal berita daring lainnya dalam meningkatkan kualitas diri. Dengan alasan demikian, penelitian ini menjadi penting untuk dilakukan.

Peneliti menggunakan empat landasan teori dalam penenlitian ini. Pertama adalah portal berita daring dalam perspektif media massa. Interconnectionnetworking atau yang disingkat internet adalah jaringan kabel telepon dan satelit yang menghubungkan computer, muncul sebagai media massa baru (Vivian, 2008: 262). Dari perkembangan internet, muncul browser (website) World Wide Web (WWW) merupakan teknologi yang tidak hanya dapat menampilkan teks namun juga dapat menampilkan suara, gambar, grafik, animasi dengan warna yang menarik bagi penggunanya. Salah satu yang memanfaatkan teknologi tersebut adalah website portal berita daring. Portal berita daring sebagai media penyalur hasrat, gagasan dan kepentingan yang telah digunakan oleh banyak masyarakat, sejalan dengan pengertian dari media 
massa, yakni media saling-silang pesan antar massa (Pareno, 2005: 7).

Landasan teori yang kedua adalah tentang menakar kredibilitas berita dengan teori objektivitas. Merujuk pemikiran McQuail (dalam Rianto dkk 2010:12), objektivitas adalah keadaan dimana berita yang disajikan oleh media benar-benar sesuai dengan fakta atau realita yang ada. Objektivitas berperan penting sebagai kunci bagi masyarakat untuk menilai apakah sebuah berita yang disajikan media dapat dipercaya atau kredibel. Sementara menurut Kamus Besar Bahasa Indonesia (KBBI), kredibilitas adalah kualitas, kapabilitas atau kekuatan untuk menimbulkan kepercayaan. Kredibilitas berita artinya kebenaran sebuah berita yang menimbulkan kepercayaan bagi masyarakat. Masyarakat akan lebih percaya pada sebuah berita yang disajikan sesuai fakta, lengkap, sarat akan informasi dan narasumber yang jelas. Melalui perspektif tersebut, peneliti menganalisis kredibilitas berita terkait dengan peristiwa Bom sarinah yang disajikan media daring dengan melihat pada teori objektivitas McQuail yakni dimensi factuality yang terdiri dari truth (kebenaran) dan relevance (relevansi). Juga melihat impartiality yang terdiri dari neutrality (netralitas) dan balance (keseimbangan).

Teori ketiga adalah aksi teror dan objektivitas pemberitaan media daring.Aksi teror yang terjadi menyebabkan hilangnya rasa aman di tengah masyarakat ditambah dengan munculnya beragam pemberitaan. Peran media daring sebagai sumber informasi bagi masyarakat, hendaknya menjaga kualitas berita dengan memperhatikan penyajian dari pemberitaan. Sumber informasi yang kredibel harus menjadi fokus utama dalam penyajian pemberitaan sehingga isi dari berita media daring dapat objektif. Idealnya media massa bertindak sebagai storyteler dari sebuah peristiwa (Prajarto, 1993: 10). Setiap pemberitaan media perlu adanya akurasi berita (Rianto, dkk 2010). Akurasi digunakan untuk mengukur tingkat kebenaran sebuah berita atau peristiwa.Portal berita daring sebagai media yang dituntut cepat dalam menyajikan berita terkait peristiwa yang terjadi namun tetap dengan kewajibannya menjaga keberimbangan berita.

\section{Metode Penelitian}

Dalam penelitian ini, peneliti menggunakan metode analisis isi. Alasan peneliti memilih analisis isi karena metode yang paling tepat diaplikasikan dalam penelitian pesan media adalah analisis isi. Menurut Holsti (dalam Rahayu, 2006: 33), metode analisis isi merupakan sebuah teknik yang dapat digunakan untuk mengambil sebuah kesimpulan dengan mengidentifikasi berbagai karakter khusus dalam sebuah pesan berita secara objektif, sistematis, dan generalis. Dengan menggunakan analisis isi, peneliti dapat mengamati pola berulang dalam 
pemberitaan Bom Sarinah yang disajikan portal berita daring Detik.com dan Kompas.com. Analisis isi juga membantu peneliti dalam menemukan struktur dalam isi pemberitaan portal berita daring Detik.com dan Kompas.com terkait pemberitaan Bom Sarinah periode 14 Januari -14 Februari 2016, Herbert J. Gans dalam Rahayu (2006:32).

Penelitian ini menggunakan pendekatan kuantitatif yang menganut paradigma positivistik. Paradigma positivistik adalah paradigma yang menyuguhkan langkah-langkah untuk menguantifikasikan realitas sosial sehingga dapat dengan mudah untuk dipahami dan diperbandingkan. Sementara pendekatan kuantitatif didefinisikan sebagai suatu teknik penelitian ilmiah yang bertujuan untuk mengetahui gambaran karakterirtik pesan berita dan menarik kesimpulan dari pesan tersebut (Eriyanto, 2011: 15). Dalam konteks ini, yang diteliti adalah isi pesan yang tampak, bukan berdasarkan makna yang dirasakan peneliti. Peneliti menggunakan analisis isi kuantitatif untuk menganalisis pesan media secara kuantitatif mengenai kredibilitas berita Bom Sarinah pada portal berita daring Detik.com dan Kompas.com periode 14 Januari -14 Februari 2016. Penelitian dilakukan pada sejumlah pemberitaan bom Sarinah pada portal berita daring Detik.com dan Kompas.com periode 14 Januari- 14 Februari 2016 dengan mengacu pada instrument pengukuran yang telah ditetapkan peneliti sebelumnya. Hasil penelitian yang berupa angka-angka akan di analisis dengan menggunakan statistik deskriptif/ inferensial.

Unit analisis yang digunakan dalam penelitian ini adalah unit rekam. Unit rekam yang dimaksud dalam penelitian ini adalah keseluruhan teks pemberitaan terkait bom Sarinah yang di posting pada portal berita daring Detik.com dan Kompas.com periode 14 Januari -14 Februari 2016. Terdapat beragam kategori pemberitaan pada kedua portal berita tersebut, namun untuk membatasi penelitian ini, peneliti memilih kategori pemberitaan tertentu untuk diteliti. Adapun kategori yang dipilih adalah hard news.Hard news didefinisikan sebagai cara media menyampaikan berita faktual kepada khalayak dengan waktu yang relatif singkat. Dalam portal berita daring, hard news memiliki nama kategori sendiri yang mana memudahkan masyarakat dalam memilih. Pada portal berita daring Detik.com peneliti memilih kategori Detik News sedangkan pada Kompas.com peneliti memilih kategori pemberitaan News Kompas karena kedua kategori ini berisi informasi update terkait perkembangan peristiwa Bom Sarinah. Adapun alasan memilih periode 14 Januari -14 Februari adalah peneliti berasumsi pada minggu-minggu tersebut peristiwa Bom Sarinah booming diberitakan. 
Populasi (universe) dalam penelitian ini adalah seluruh berita bom sarinah periode 14 Januari-14 Februari 2016 pada rubrik detik News di portal berita daring Detik.com dan rubrik News Kompas pada portal berita daring Kompas.com. Peneliti mengumpulkan 118 berita bom Sarinah pada rubrik Detik News dan 91 berita pada rumbik News Kompas periode 14 Januari-14 Februari 2016. Sementara teknik sampling yang digunakan peneliti dalam penelitian ini adalah teknik sampling berdasarkan pendapat Silaen dan Widiyono (2013: 88), yaitu tidak ada ketentuan yang pasti terkait besarnya sampel, yang penting representatif (terwakilkan). Populasi lebih dari 100 maka dapat diambil 10\%-50\% dari populasi. Berdasarkan penjelasan diatas, peneliti mengambil 50\% dari jumlah populasi. Peneliti menarik sampling berdasarkan metode probability yaknisimple random sampling (sampel acak sederhana) sehingga setiap anggota populasi memiliki peluang yang sama sebagai sampel. Peneliti meyakini bahwa setiap sampel yang diambil dapat mewakili isi dari keseluruhan penelitian. Jadi, total keseluruhan sempel dalam penelitian ini adalah 105 berita terkait bom Sarinah. Adapun pembagiannya yakni 59 berita portal berita daring Detik.com dan 46 berita portal berita daring Kompas.com.

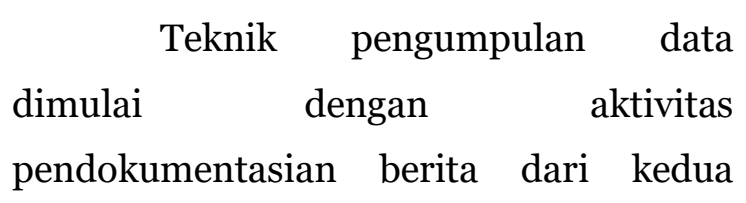

portal berita daring yang diteliti. Keseluruhan judul berita terkait isu Bom Sarinah diseleksi guna menetapkan gambaran awal berapa judul berita selama terjadinya peristiwa Bom Sarinah. Proses selanjutnya adalah menentukan sampel. Akhirnya, diputuskan untuk menganalisis data pemberitaan Bom Sarinah pada rubrik Detik News dan News Kompas yakni 50\% pada masing-masing rubrik periode 14 Januari-14 Februari 2016. Total yang dianalisis, yakni sebesar 104 berita yang terdiri dari 59 berita berasal dari portal berita daring Detik.com dan 45 berita berasal dari portal berita daring Kompas.com.

Data yang terkumpul kemudian dioperasikan melalui lembar koding, yakni proses pemberian identitas berdasarkan instrumen dalam coding sheet. Data yang dihasilkan kemudian diolah menggunakan program komputer Excel. Dalam hal ini, data yang ditemukan, dipersentasekan dan dibentuk pie chart. Hasil persentase yang ditemukan kemudian dilakukan klasifikasi berjenjang melalui skala pengukuran. Langkah selanjutnya pembobotan atau penyekoran dari setiap unit analisis yang akhirnya ditotal dan digunakan untuk menarik kesimpulan yang menjawab rumusan masalah penelitian ini. Hasil analisis diambil berdasarkan langkah pengukuran terakhir, yakni pembobotan atau penyekoran yang menyajikan perbandingan nilai kredibilitas berdasarkan nilai dari tiap subdimensi 
yakni factualness, accuracy, completeness, relevance, balance dan neutrality. Terakhir, penarikan kesimpulan perbandingan nilai kredibilitasportal berita daring Detik.com dan Kompas.com pada pemberitaan Bom Sarinah periode 14 Januari-14 Februari 2016 berdasarkan total nilai factuality dan impartiality.

\section{Analisis dan Pembahasan}

\section{Hasil Uji Reliabilitas dan Pengukuran}

Uji reliabilitas dilakukan untuk meyakini kesahihan kategori dan klasifikasi yang digunakan dalam penelitian. Tolak ukur yang digunakan peneliti dalam uji reliabilitas adalah tolak ukur Holsti yang menetapkan standar minimum 0,75 atau 75\% (Kriyantono, 2009:237). Artinya, jika hasil perhitungan menunjukkan angka reliabilitas diatas 0,75 berarti alat ukur ini benar-benar reliable. Tetapi jika sebaliknya, berarti alat ukur (coding sheet) bukan alat yang reliable. Hasil uji reliabilitas yang dilakukan dalam penelitian kredibilitas portal berita daring dalam pemberitaan peristiwa Bom Sarinah periode 14 Januari - 14 Februari 2016, mencapai angka $87 \%$, dimana angka ini lebih dari standar minimum yakni $75 \%$. Artinya, unit analisis yang terdapat pada coding sheet dinyatakan sahih.Lembar coding sheet dapat digunakan sebagai alat ukur yang reliable.

Penenlitian ini menggunakan dua kategori penyekora, yakni penyekoran berupa persentase yang dihitung berdasarkan frekuensi dan penyekoran yang menghasilkan klasifikasi berjenjang melalui skala pengukuran.Penyekoran pertama digunakan untuk melihat porsi penilaian pada setiap kategori dimensi unit-unit analisis. Sementara penyekoran kedua untum mengkategorikan penilaian pada setiap dimensi dan sub dimensi unit analisis. Frekuensi penyekoran yang berupa persentase dari masing-masing unit analisis, dilakukan akumulasi untuk menghasilkan nilai berjenjang pada setiap kategori unit nalisis. Akumulasi nilai minimal dan maksimal dikelompokkan dalam range tertentu dengan memeberikan nilai mulai dari sangat baik, baik, cukup, dan buruk. Pengkategorian dilakukan guna membuat standarisasi dan mempermudah penggolongan penilaian pada setiap dimensi unit analisis.

Tabel 1

Tabel Range dan Value berjenjang.

\begin{tabular}{|l|l|l|l|l|}
\hline \multicolumn{5}{|c|}{ KATEGORI PENILAIAN } \\
\hline Sangat baik & Baik & Cukup & Buruk & Sangat buruk \\
\hline $81 \%-100 \%$ & $61 \%-80 \%$ & $41 \%-60 \%$ & $21 \%-40 \%$ & $0 \%-20 \%$ \\
\hline
\end{tabular}




\section{Penyekoran}

Penyekoran bermanfaat untuk melihat porsi kredibilitas portal daring Detik.com dan Kompas.com dalam menyajikan berita peristiwa Bom Sarinah periode 14 Januari- 14 Februari 2016 pada setiap kategori dimensi unit-unit analisis. Sebelum menjelaskan lebih lanjut persoalan penyekoran, peneliti akan kembali menjelaskan bahwa dalam penelitian ini peneliti mengukur kredibilitas berita dengan teori objektivitas berita Denis McQuail yakni dimensi factuality dan dimensi impartiality dengan berbagai unit analisis didalamnya. Penyekoran diberikan kepada kedua dimensi yakni dimensi factuality dan dimensi imparciality dengan total 100. Selanjutnya sekor 100 tersebut dibagi dua, dimana dimensi factuality mendapatkan skor 70, selanjutnya dibagi kedalam 20 unit analisis penelitian sehingga masingmasing unit analisis penelitian mendapatkan nilai 3,5. Sedangkan dimensi impartiality mendapatkan skor 30, selanjutnya dibagi kedalam 6 unit analisis penelitian sehingga masing-masing unit analisis penelitian mendapatkan nilai 5 . Selanjutnya, untuk mendapatkan skor yang diinginkan, peneliti mengalikan tiap nilai unit analisis dengan nilai persentase yang telah didapatkan pada tiap unit analisis.Hasil yang ditemukan dalam penyekoran ini adalah nilai factualness, accuracy, completeness, relevance, balance, neutralitu dan yang terakhir adalah perbandingan nilai kredibilitas dari kedua portal daring yakni portal daring Detik.com dan Kompas.com.

\section{Hasil analisis Isi Berita}

Kefaktualan Berita. Subdimensi factualness adalah derajat kefaktualan sebuah berita yang berkaitan dengan tingkan hubungan antara teks yang disajikan media dengan realita yang ada. Berdasarkan hasil analisis subdimensi factualness yang diukur berdasarkan sub unit analisis letak main point, jenis main point, density, breadth, depth, penggunaan istilah khusus yang tidak disertai keterangan dan kejelasan sumber rujukan, nilai factualness Kompas.com lebih tinggi, yakni total nilai 13,27 dibandingkan dengan Detik.com dengan total nilai 13,15. Hal ini menunjukkan bahwa tingkat kefaktualan berita yang disajikan Kompas.com lebih baik dibandingkan dengan nilai berita yang disajikan Detik.com. 


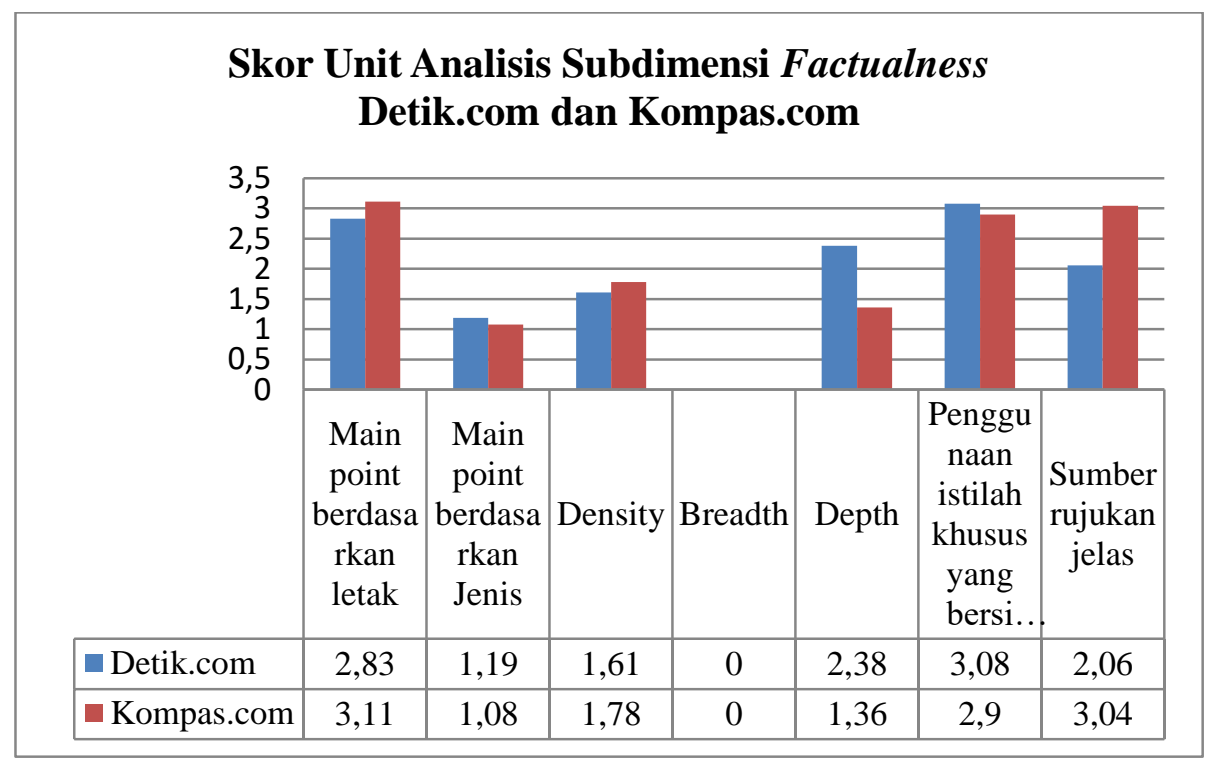

Grafik 1

\section{Skor Unit Analisis Subdimensi Factualness Detik.com dan Kompas.com}

Akurasi. Akurasi merupakan subdimensi yang berkaitan erat dengan kualitas sebuh berita yang disajikan media dan kredibilitas sebuah berita dihadapan audiensnya. Akurasi diukur berdasarkan sub unit analisis cek dan ricek, pencantuman sumber berita, kesesuaian pengutipan, relevansi sumber berita, kesesuaiaan ejaan dan tanda baca, kesesuaiaan judul da nisi berita, serta kesesuaiaan isi dan gambar. Berdasarkan hasil penelitian ini, nilai accuracy Kompas.com lebih baik dibandingkan dengan nilai accuracy Detik.com. Total nilai accuracy Kompas.com berdasarkan tujuh sub unit analisis adalah 20,39 sementara Detik.com adalah 17,98. Hal ini menunjukkan bahwa dari segi kualitas berita yang disajikan, Kompas.com lebih berkualitas dibandingkan dengan Detik.com.

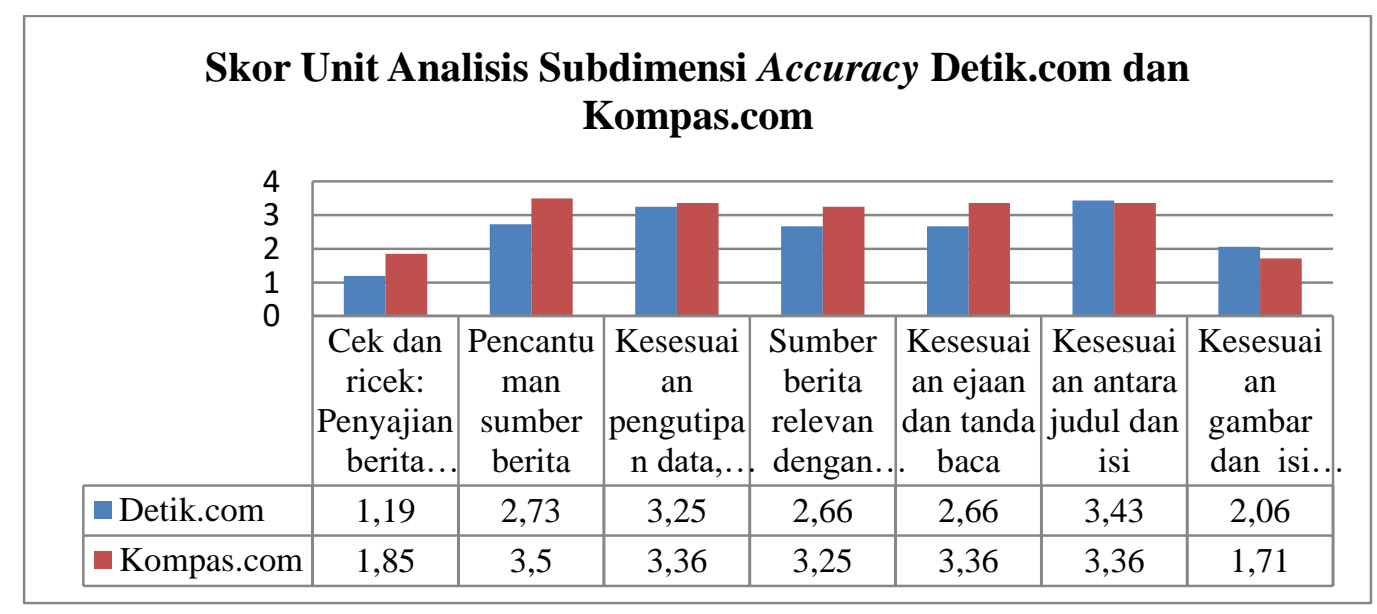

Grafik 2

Skor Unit Analisis Subdimensi Accuracy Detik.com dan Kompas.com 
Kelengkapan. Completeness merupakan subdimensi yang dapat menunjukkan kelayakan sebuah berita yang disajikan berdasarkan kelengkapan informasi yang terkandung dalam sebuah berita tersebut.Kelengkapan ini diukur berdasarkan kelengkapan unsur berita yakni $5 \mathrm{~W}+1 \mathrm{H}$ (what, when, where, who, why and how).Berdasarkan hasil analisis kelengkapan berita yang disajikan
Detik.com dan Kompas.com, nilai kelengkapan berita Kompas.com lebih tinggi dibandingkan dengan Detik.com.total nilai kelengkapan Kompas.com yakni 2,24 sementara Detik.com yakni 1,54. Hal ini menunujukkan bahwa informasi berita yang disajikan Kompas.com lebih lengkap dibandingkan dengan Detik.com.

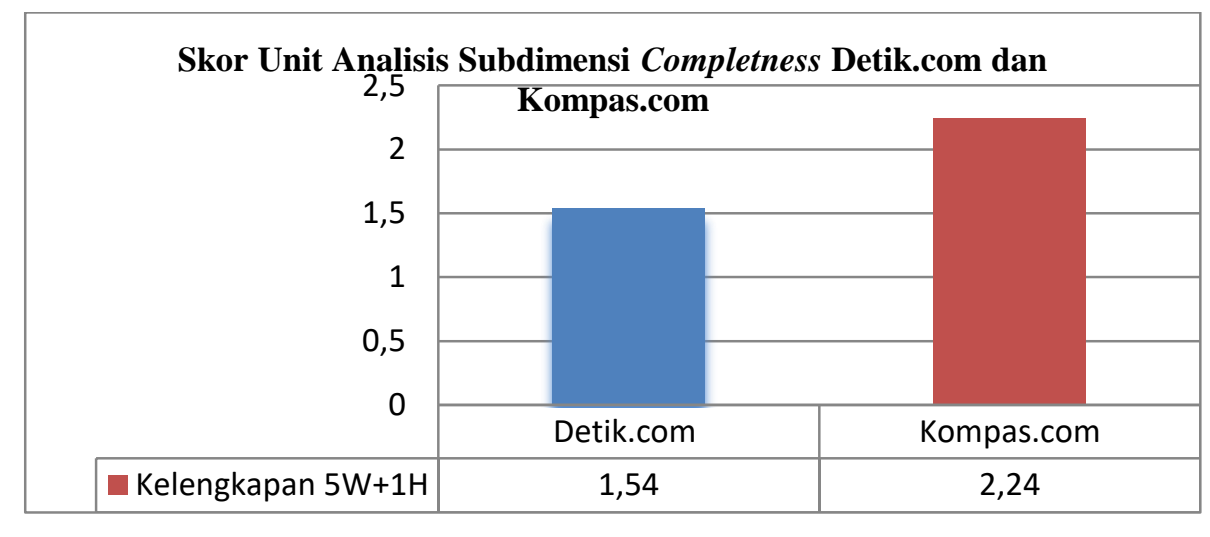

Grafik 3

Skor Unit Analisis Subdimensi Completness Detik.com dan Kompas.com

Relevansi. Relevance berkaitan erat dengan kualitas sebuah berita yakni nilai yang terkandung dalam sebuah berita.Dalam penelitian ini, relevance diukur berdasarkan significance, prominence, magnitude, timeliness dan proximity. Berdasarkan hasil analisis yang dilakukan peneliti berdasarkan lima sub unit analisis diatas, nilai berita yang disajikan Kompas.com lebih tinggi dibandingkan nilai berita yang disajikan Detik.com. hal ini dapat ditujukkan dengan total nilai yang dimiliki Kompas.com, yakni 12,37 sementara Detik.com yakni 11,64 . 


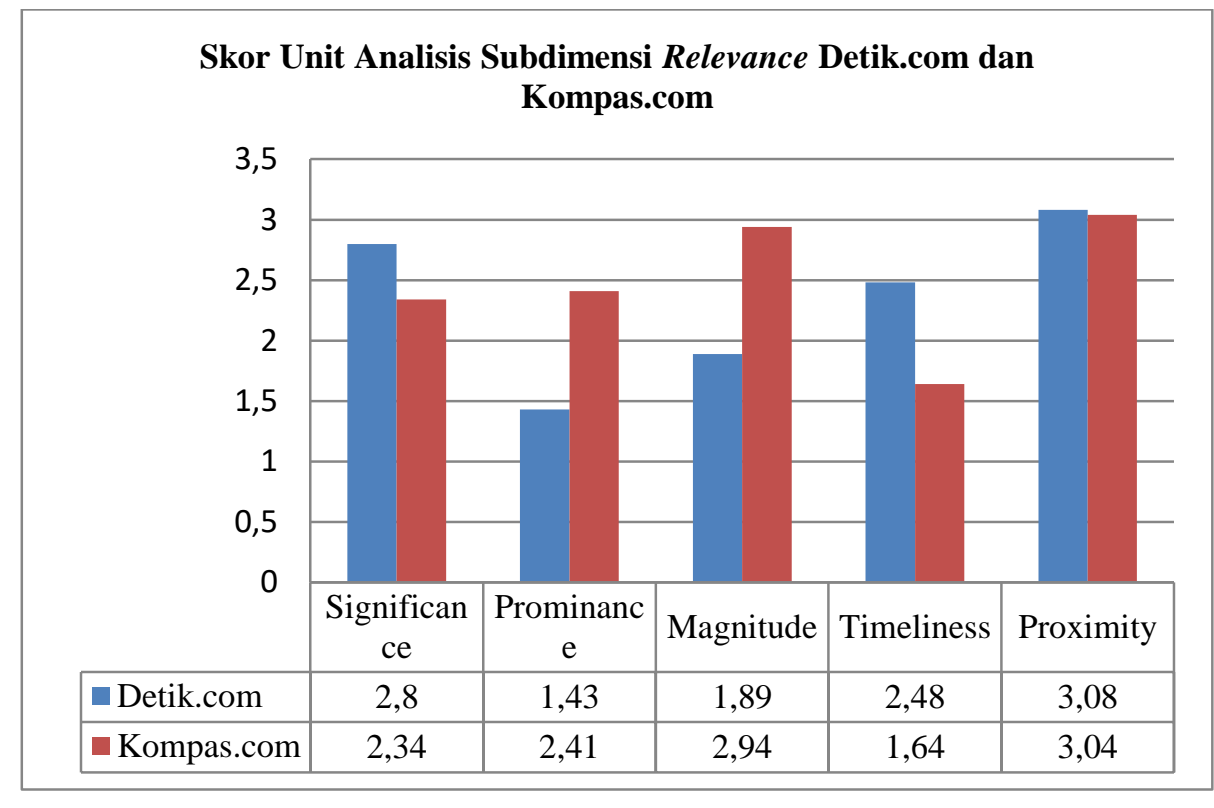

Grafik 4

\section{Skor Unit Analisis Subdimensi Relevance Detik.com dan Kompas.com}

Balance. Subdimesni balance diartikan sebagai keseimbangan sebuah media dalam menyajikan berita atau ketidak berpihakan yang ditunjukkan oleh sebuah media dalam pemberitaannya. Dalam penelitian ini, balance diukur berdasarkan sourcebias dan tidak adanya slant. Berdasarkan hasil analisis dalam penelitian ini, nilai balance antara Detik.com dan Kompas.com adalah sama yakni total nilai 5. Yang menunjukkan kedua portal berita tidak terdapat source bias maupun slant.

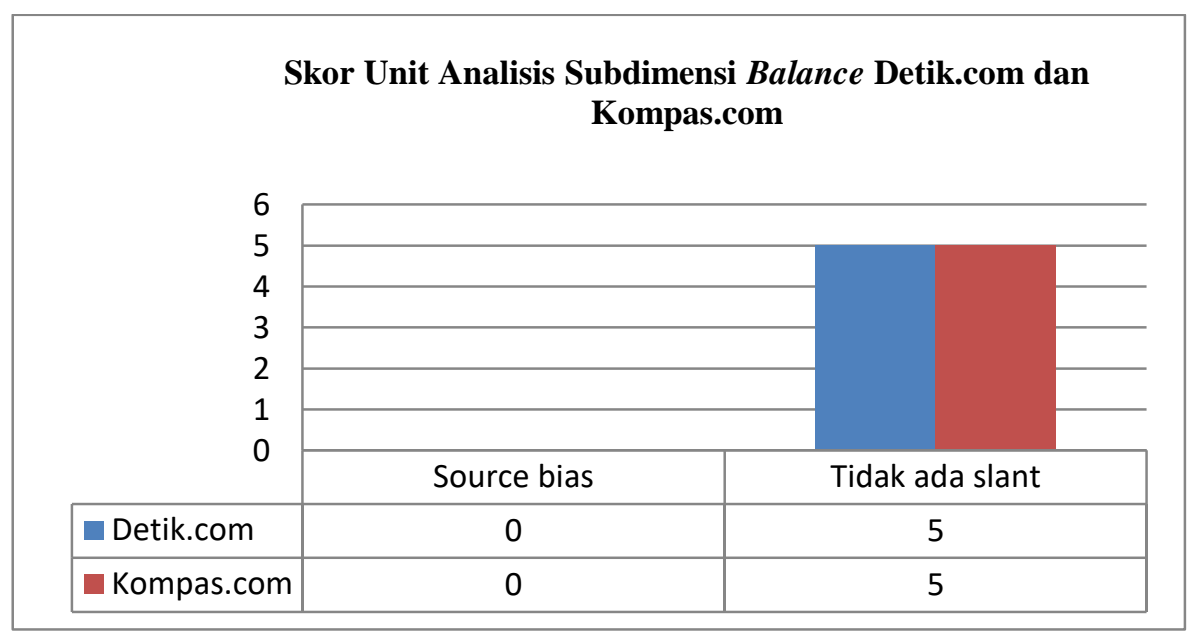

Grafik 5

Skor Unit Analisis Subdimensi Balance Detik.com dan Kompas.com 
Netralitas. Penyajian berita harus bersifat netral tanpa adanya keberpihakan, tanpa adanya pihak yang diuntungkan maupun dirugikan berdasarkan berita yang disajikan oleh media.Dalam penelitian ini netralitas diukur berdasarkan sensasionalime, stereotype, juxtaposition dan linkage.
Berdasarkan hasil penelitian ini, total nilai netralitas Kompas.com lebih tinggi yakni 18,65 dibandingkan dengan Detik.com dengan total nilai 17,70. Hal ini menunjukkan sikap netral dari penyajian berita Kompas.com lebih baik dibandingkan dengan Detik.com.

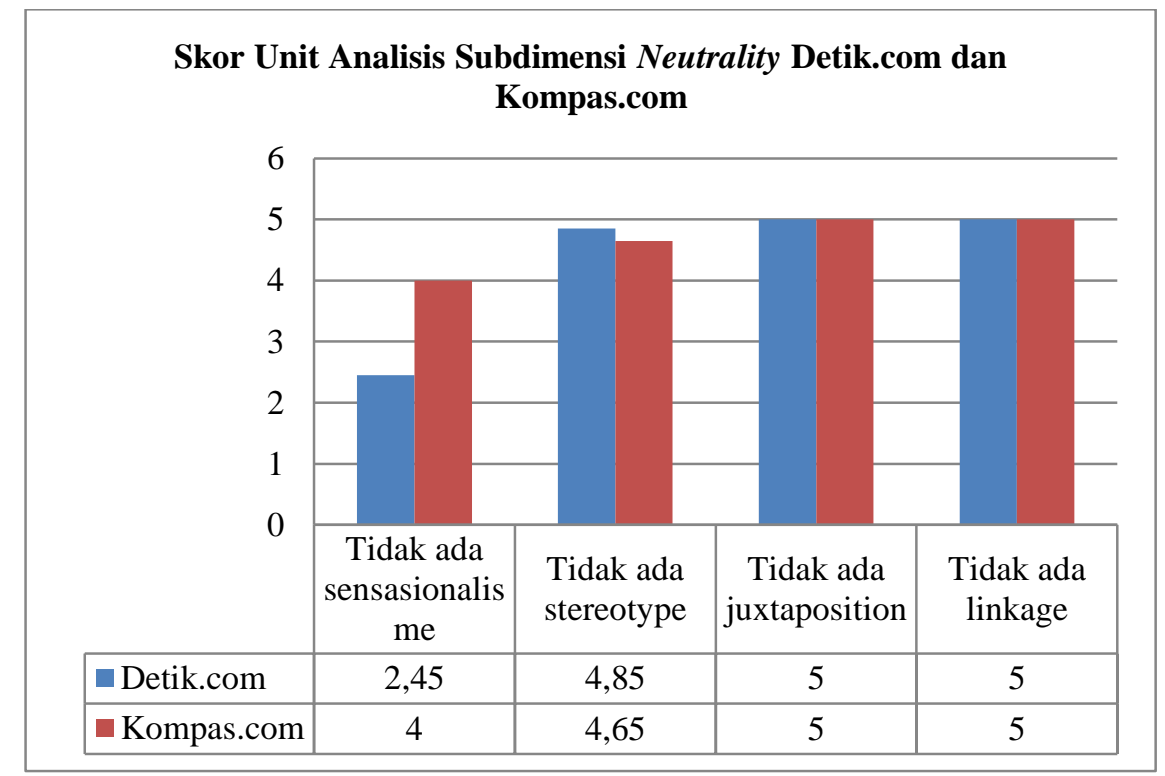

Grafik 6.

\section{Skor Unit Analisis Subdimensi Neutrality Detik.com dan Kompas.com}

Faktualitas. Factuality atau faktualitas dapat diartikan sebagai kualitas informasi sebuah berita yang disajikan oleh suatu media yang menyangkut pada aspek reliabilitas dan kredibilitas.Berdasarkan hasil analisis penelitian ini, total nilai factuality
Kompas.com lebih tinggi yakni 48,29 dibandingkan dengan total nilai Detik.com yakni 44,35. Hal ini menunjukkan kualitas berita yang disajikan oleh Kompas.com lebih baik dengan kualitas berita yang disajikan Detik.com. 


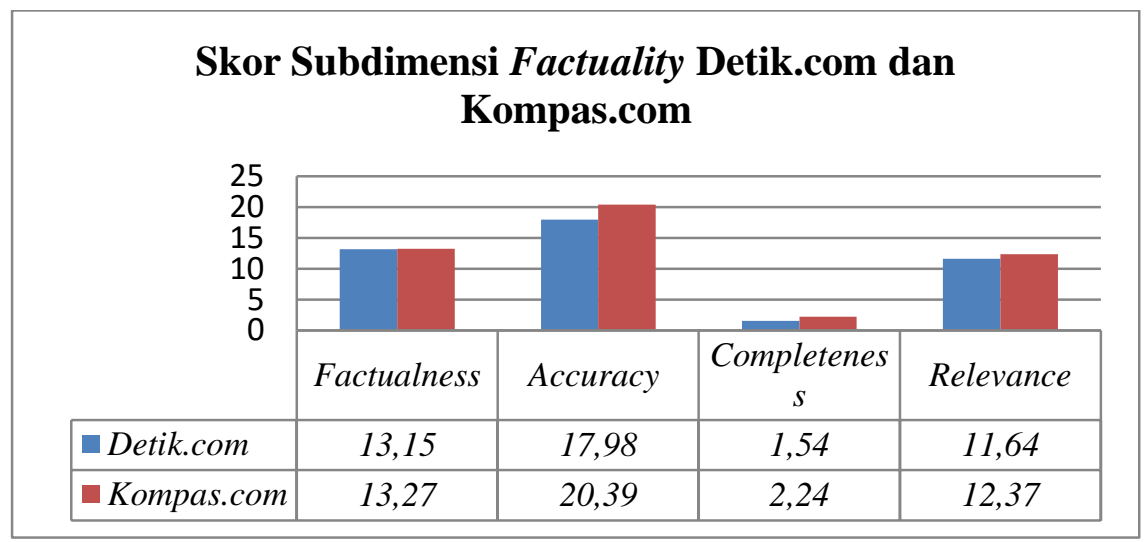

Grafik 7

\section{Skor Subdimensi Factuality Detik.com dan Kompas.com}

Imparsialitas. Dimensi impartiality berkaitan dengan aspek ketidak berpihakan sebuah berita yang disajikan media yang diukur berdasarkan balace dan neutrality.Berdasarkan hasil analisis penelitian ini, total nilai impartiality Kompas.com lebih tinggi dibandingkan dengan total nilai
Detik.com.total nilai Kompas.com yakni 23,65 sedangkan total nilai Detik.com yakni 22,30. Hal ini menunjukkan bahwa tingkan netralitas berita yang disajikan Kompas.com lebih tinggi dibandingkan dengan tingkat netralitas berita yang disajikan Detik.com.

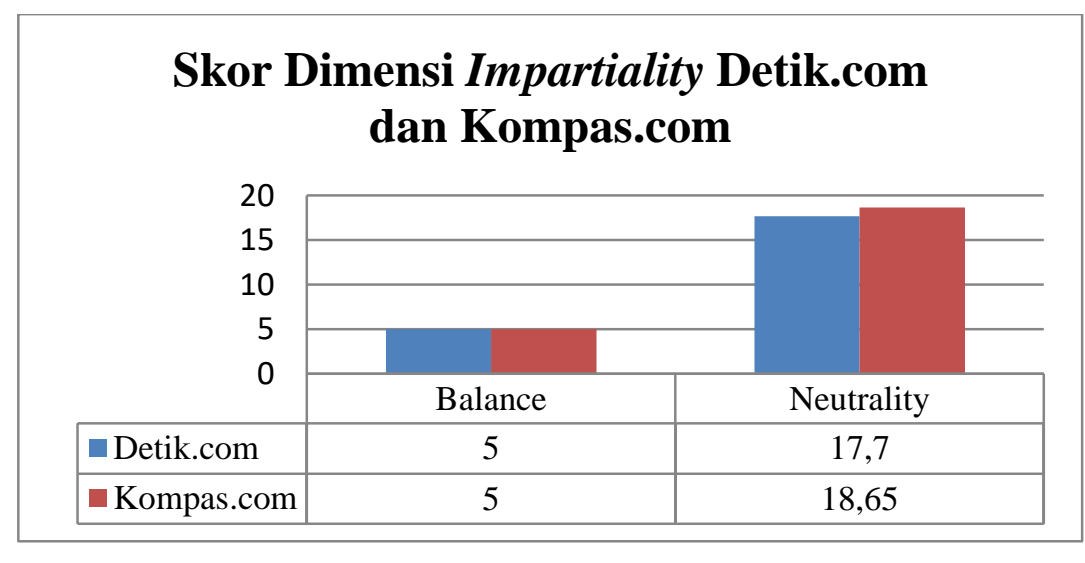

Grafik 8

\section{Skor Dimensi Impartiality Detik.com dan Kompas.com}

Kredibilitas. Nilai kredibilitas dapat dilihat dari akumulasi total nilai dimensi factuality dan total nilai dimensi impartiality. Berdasarkan hasil analisis penelitian ini, total nilai factuality yang jumlahkan dengan impartiality 
Kompas.com lebih tinggi dengan total 71,94 sementara total nilai fatuality yang dijumlahkan dengan Impartiality Detik.com adalah 66,65. Hal ini menunjukkan nilai kredibilitas Kompas.com dalam menyajikan berita lebih tinggi dibandingkan dengan nilai kredibilitas Detik.com

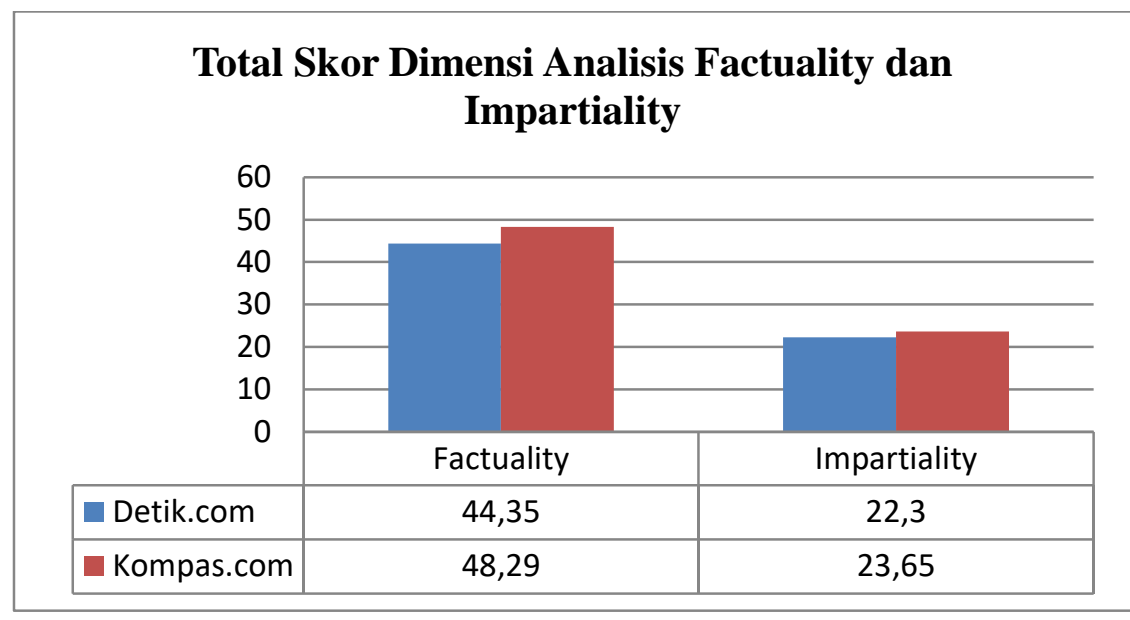

Grafik 9

Total Skor Dimensi Analisis Factuality dan Impartiality

\section{Penutup}

\begin{tabular}{ccc}
\multicolumn{3}{c}{ Berdasarkan hasil skoring } \\
keenam aspek penelitian & yakni
\end{tabular} Factualness, accuracy, completeness, relevance, balance dan neutrality beserta indicator di dalamnya, dapat ditarik kesimpuln bahwa nilai kredibilitas portal berita daring Kompas.com lebih tinggi dibandingkan dengan nilai kredibilitas Detik.com dalam pemberitaan peristiwa Bom Sarinah periode 14 Januari- 14 Februari 2016. Portal berita daring Kompas.com memiliki nilai kredibilitas 71,94 sementara portal berita daring Detik.com memiliki nilai kredibilitas 66,65. Hal ini dapat dilihat dari keenam aspek penelitian dimana nilai terhadap portal berita daring Kompas.com selalu lebih tinggi dibandingkan dengan Detik.com. Nilai factualness Kompas.com 13,27 sementara Detik.com 13,15, nilai accuracy Kompas.com 20,39 sementara Detik.com 17,98 nilai completeness Kompas.com 2,24 sementara Detik.com 1,54, nilai relevance Kompas.com 12,37 sementara Detik.com 11,64, nilai balace baik portal Kompas.com maupun Detik.com adalah 5 dan nilai neutrality Kompas.com 18,65 sementara Detik.com 17,7 .

Berdasarkan temuan di atas, beberapa saran bagi penelitian selanjutnya, yakni dapat melakukan penelitian terkait dengan kredibilitas media pada media lainnya baik media 
cetak, media elektronik atau pun media baru tentunya dengan objek penelitian berupa portal berita daring yang berbeda dari penelitian ini. Durasi dalam penenlitianpun dapat ditambah tidak hanya dalam hitungan bulan, bahkan dalam hitungan tahun agar ditemukan hasil penelitian yang lebih valid. Selain itu, dapat dilakukan penelitian dengan rubric yang berbeda yang terdapat pada media daring, karena akan lebih baik apabila menarik kesimpulan terkait kredibilitas suatu portal berita daring dengan menganalisis keseluruhan rubric yang terdapat pada portal berita daring tersebut. Untuk penelitian selanjutnya akan lebih menarik apabila dapat menggunakan metode penenlitian lainnya seperti framing dan lain sebagainya dalam melakukan penelitian terkait dengan portal berita daring. Sehingga diharapkan penenlitian tersebut nantinya dapat menambah literature dan pengetahuan yang lebih mendalam mengenai kredibilitas portal berita daring. 


\section{Daftar Pustaka}

Christofiana, Rosa. 2014. "Objektivitas Berita Bias Gender Dalam Media Online (Analisis Isi Kuantitatif Objektivitas Berita Kecelakaan Novia Amalia dalam Portal Berita Detik.com Periode 11 Oktober-11 November 2012).”Skripsi Sarjana, Fakultas Ilmu Sosial dan Ilmu Politik, Universitas Atma Jaya, Yogyakarta.

Eriyanto.(2004). Analisis Wacana, Pengantar Analisis Isi Media. Yogyakarta: LKIS.

Eriyanto. (2011). Analisis Isi: Pengantar Metodologi untuk Penelitian Ilmu Komunikasi dan Ilmu-ilmu Sosial Lainnya. Jakarta: Kencana Prenada Media Group.

Habibi, Zaki. "Citizen Journalism Dan Makna Berita Di Era Informasi”, Jurnal Komunikasi, Vol.1 (April 2007), hal 1-10.

Kriyantono, Rachmat. (2009). Teknik Praktis Riset Komunikasi. Jakarta: Kencana.

Pareno, Sam Abede. (2005). Media Massa antara Realitas dan Mimpi. Surabaya: Penerbit Papyrus

Prajarto, Y.A. Nunung. (1993). Media Berita dalam Sebuah Konflik.Yogyakarta: FISIPOLUGM.
Rahayu.(2006). Menyingkap Profesionalisme Kinerja Surat Kabar Indonesia.Yogyakarata: Pusat Kajian Media dan Budaya Populer, Dewan Pers, dan Departemen Komunikasi dan Informasi.

Silaen, Sofar, Widiyanto. (2013). Metodologi Penelitian Sosial Untuk Penulis Skripsi Dan Tesis.Jakarta: In Media.

Rianto, Puji, et.al. (2010). Menyapa Publik: Analisis Berita LPP RRI Pro 3 dan Program Indonesia Menyapa. Yogyakarta: Puslitbangdiklat LPP RRI.

Vivian, John. (2008). Teori komunikasi Massa (Edisi Kedelapan). Jakarta: Kencana.

Yuda, Fransiscus. 2013. "Kelayakan Berita Citizen Journalism (Studi Analisis Isi Kuantitatif Mengenai Kelayakan Berita dalam Kolom Citizen Journalism Surat Kabar Harian Tribun Jogja periode November 2012- Februari 2013).” Skripsi Sarjana, Fakultas Ilmu Sosial dan Ilmu Politik, Universitas Atma Jaya, Yogyakarta. 
Jurnal komunikasi, Volume 12, Nomor 1, Oktober 2017 